Acta Universitatis Wratislaviensis • No 3982

Literatura i Kultura Popularna XXV, Wrocław 2019

https://doi.org/10.19195/0867-7441.25.24

\title{
Nina Ćwiklak
}

ORCID: 0000-0001-5735-1272

Uniwersytet Wrocławski

\section{Edgar G. Ulmer - Roger Corman Stuart Gordon. Filmowe adaptacje opowiadania Edgara Allana Poego Czarny kot}

Słowa kluczowe: literatura romantyzmu, gotycka powieść grozy, Czarny kot Edgara Allana Poego, adaptacje filmowe

Keywords: romantic literature, gothic novel, Edgar Allan Poe's The Black Cat, film adaptations

Twórczość Edgara Allana Poego cieszy się niesłabnącym zainteresowaniem. Nieustannie ponawiane są próby jej reinterpretacji. Proces ten znajduje odzwierciedlenie w licznych odniesieniach do dzieł tego autora w kulturze popularnej. Czynnikiem, który wpływa na tak duże zainteresowanie ze strony twórców i odbiorców, jest nieskrępowana wyobraźnia Poego, zupełnie niepodobna do wyobraźni jakiegokolwiek innego twórcy. Jak pisze Władysław Kopaliński:

Ta właśnie nieprzemożna, zniewalająca moc wyobraźni, która może być cechą tylko prawdziwie wielkiego twórcy, pociąga nas i czaruje u poety, który przeszedł przez życie (jak to sam pięknie w Kruku napisał) dreaming dreams no mortal ever dared to dream before śniąc sny, których śmiertelnik żaden przed nim nie śmiał śnić ${ }^{1}$.

Wyjątkowy potencjał wyobraźni Poego inspirował, ale i przerażał. Fascynacji tym, co niezwykłe i niesamowite, jedyne w swoim rodzaju i niepowtarzalne, zawdzięczają utwory amerykańskiego poety nieustające powodzenie u czytelników oraz artystów kina, którzy dostrzegli w nich bardzo atrakcyjny materiał do adaptacji filmowych.

1 W. Kopaliński, Przedmowa, [w:] E.A. Poe, Opowiadania, przeł. S. Wyrzykowski, Warszawa 1989, s. 21. 
Czarny kot (The Black Cat) należy do najbardziej znanych dzieł Poego. Nowela została opublikowana 19 sierpnia 1843 roku na łamach magazynu „The Saturday Evening Post". Jest to historia pogrążonego w monomanii bohatera, który w alkoholowym szale krzywdzi Plutona, ukochanego kota swojej żony, wydłubując mu nożem oko. Od tej pory czuje do zwierzęcia ogromny wstręt, który z czasem wzrasta. Początkowe wyrzuty sumienia szybko ustępują miejsca maniakalnej obsesji na punkcie tytułowego czarnego kota. Pewnego razu pijany bohater obwiązuje wokół szyi zwierzęcia pętlę i wiesza je na drzewie. Kot umiera. Chwilę później w domu oprawcy wybucha pożar, który zmusza mieszkańców do ucieczki. $\mathrm{Z}$ budynku pozostaje tylko jedna ściana. Bohater dostrzega na niej zarys ogromnego kota powieszonego na linie, próbuje jednak logicznie to sobie wytłumaczyć i zapomnieć o całym zdarzeniu. Jakiś czas później spotyka kota prawie takiego samego jak Pluton i zabiera go do domu. Wkrótce zaczyna bać się zwierzęcia. Gdy schodzi do piwnicy, a kot wchodzi mu pod nogi, bohater popada w szał i rzuca się na niego z siekierą. Niechcący trafia w swoją żonę, która próbując uratować pupila, zastępuje mężowi drogę. Bohater zamurowuje zamordowaną żonę w piwnicznej wnęce. Nie może znaleźć kota, więc sądzi, że przestraszone zwierzę uciekło. Wkrótce mężczyźnie składa wizytę policja, zaalarmowana przez zaniepokojonych krzykami sąsiadów, i przeszukuje jego mieszkanie. Kiedy policjanci nie znajdują niczego podejrzanego i chcą opuścić dom bohatera, ten sugeruje im sprawdzenie piwnicy. Gdy pewny siebie uderza w świeżo wymurowaną ścianę, rozlega się głośny pisk. Policjanci rozbierają ścianę. Za nią znajduje się trup żony bohatera i miauczący czarny kot.

Tak samo jak w innych utworach Poego w Czarnym kocie czytelnik spotyka się z siecią niedopowiedzeń. Autor nie doprecyzowuje przestrzeni, nie zdradza imienia bohatera ani informacji o jego pochodzeniu i sytuacji społecznej. Odbiorca może zastanawiać się, czy cała fabuła nie dzieje się wyłącznie w umyśle neurastenicznego bohatera-narratora, który swoją historię podsumowuje w następujący sposób:

Być może, iż kiedyś znajdzie się umysł, co zdoła me urojenia sprowadzić w dziedzinę zjawisk już dawno znanych, co, mając więcej spokoju i logiki, a znacznie mniej pobudliwości ode mnie, nie dostrzeże w okolicznościach, które wspominam z przerażeniem, nic okrom zwykłego następstwa najnaturalniejszych przyczyn i skutków².

W tych słowach można odczytać postulat bardziej naukowego podejścia do zjawisk psychologicznych czy też podjętą przez autora próbę racjonalnego wyjaśnienia niezwykłych fenomenów i doznań psychicznych człowieka, do czego jeszcze powrócę.

2 E.A. Poe, Opowiadania, przeł. S. Wyrzykowski, t. 1, Warszawa 1989, s. 378. 


\section{Motywy romantyczne w Czarnym kocie}

Poe na własny użytek rozbudował i przekształcił figurę bohatera romantycznego. Tworzone przez niego postaci literackie służą nierzadko dzisiejszym artystom za wzorce kompozycyjne. Według Żanety Nalewajk:

Współdecyduje o tym to, że kreacje bohaterów w nowelach Poego na ogół zyskiwały umocowanie w obrębie konwencji łatwych w odbiorze, które są fabularnie samowystarczalne, a jednocześnie postaci te nie dają się zredukować do klasycznych schematów, nie są ich prostym odwzorowaniem i dzięki temu okazują się wyjątkowo podatne na wielość interpretacji ${ }^{3}$.

Podobnie jak Friedrich Schiller w Zbójcach (Die Räuber, 1781; pol. 1803) czy lord Byron w Giaurze (Giaur, 1813; pol. 1835) Poe czyni bohaterami swoich nowel osoby nazwane przez Nalewajk „rozchwianymi” i „nietożsamymi ze sobą"4. Bohaterem Czarnego kota jest alkoholik z problemami psychicznymi. Czytelnik ma powody, aby podawać w wątpliwość jego wiarygodność. Bohater-narrator zapewnia nas o swoim zdrowiu psychicznym, jednak, ze względu na przekazane przez niego informacje, mamy podstawy, aby mu nie wierzyć. Albowiem kto zupełnie zdrowy okrutnie dręczy zwierzę i oskarża je o własne porażki, uchylając się od odpowiedzialności za dokonane czyny? ${ }^{5}$ Motywacje tworzonych przez amerykańskiego pisarza postaci można uzasadniać ich podłożem psychicznym (jeśli czytelnik przyjmie, że opowiadana historia to wytwór chorej wyobraźni bohatera) bądź fantastycznym (jeżeli założy się, że bohater opowiada o wydarzeniach niezwykłych):

Współistnienie w nowelach Poego motywacji psychologicznej z motywacją fantastyczną nie pozwala na definitywne określenie zasad rządzących światem przedstawionym. Zdarzenia dają się wprawdzie wyjaśnić w ramach jednolitego systemu motywacyjnego, ale szybko okazuje się, że system motywacyjny nie jest systemem jedynym ${ }^{6}$.

Nalewajk podkreśla, że Poe często stawiał stworzone przez siebie postaci w sytuacjach granicznych. Tak właśnie dzieje się w Czarnym kocie. Zmagający się z własną psychiką bohater staje w obliczu zbrodni, której dokonał. Pisarz zadaje pytania o racjonalność motywacji ludzkiej i o istnienie zła w świecie.

Nie tylko w twórczości Poego, lecz także w literaturze romantycznej innych krajów kot należy do często wykorzystywanych symboli. Mianowicie na przykład

3 Ż. Nalewajk, Postać literacka w nowelistyce Poego. Zasady konstrukcji, [w:] Edgar Allan Poe zwielokrotniony. W kręgu literatury, malarstwa i filmu, red. E. Szczęsna, P. Kubiński, Warszawa 2010, s. 34.

4 Ibidem, s. 24.

${ }^{5}$ Narrator o niejasnym statusie występuje w większości nowel Poego. W Prawdziwym opisie wypadku z Panem Waldemarem (The Facts in the Case of M. Valdemar, 1845; pol. 1867 jako Istotna prawda o znanym zdarzeniu z osoba niejakiego Waldemara) czytelnik nie może być pewny nawet tego, czy osoba mówiąca żyje.

6 Ż. Nalewajk, op. cit., s. 27-28. 
w niemieckiej literaturze kot uważany był wręcz za symbol romantyzmu ${ }^{7}$. Pojawił się on w powieści Novalisa Henryk von Ofterdingen (Heinrich von Ofterdingen, 1800; pol. 1914), w której symbolizował romantyczną tęsknotę. Motyw kota kojarzy się jednak znacznie częściej z magią i przesądami. Wspomina o tym sam bohater-narrator Czarnego kota:

Mówiąc o jego [kota] inteligencji, żona moja, w głębi duszy nieco przesądna, czyniła nieraz aluzje do starodawnego, ludowego zabobonu, wedle którego wszystkie koty czarne są przedzierzgnionymi w zwierzęta czarownicami ${ }^{8}$.

W ludowych wierzeniach postać kota mogły przybrać nie tylko czarownice, lecz także rozmaite demony. Spotkanie z czarnym kotem zwiastowało nieszczęście. Zwierzę mogło być przyczyną niepowodzeń, choroby, a nawet śmierci. Kot z opowiadania Poego nie bez powodu nosi imię rzymskiego boga podziemi Plutona. Według Piotra Kowalskiego niektóre wierzenia wiązały kota z sacrum. Jego dzikość, tajemniczość, niezależność i wolność, a także umiejętność bezszelestnego poruszania się i zdolność widzenia w mroku, czyniły ze zwierzęcia istotę powiązaną ze strefą śmierci ${ }^{9}$. Sam Poe był właścicielem kota, jednak w przeciwieństwie do wykreowanego przez siebie bohatera darzył on zwierzę sympatią i pozwalał mu przysiadać na swoim ramieniu ${ }^{10}$.

Bohater opowiadania z początku zaprzyjaźniony był z kotem. Później popadł w alkoholizm i zaczął mieć obsesję na punkcie zwierzęcia, które oskarżał o spowodowanie własnych, zbrodniczych czynów.

Z szeroko rozwartą, krwawą paszczą i pałającym jednym okiem siedział na głowie jego [trupa] ohydny potwór, co najpierw podstępnie popchnął mnie do zbrodni, po czym swym ostrzegawczym głosem wydał mnie w ręce kata ${ }^{11}$.

Kot jest więc dla bohatera nie tylko impulsem do popełnienia zbrodni, ale też przyczyną jej odkrycia.

Literatura romantyczna definiowała bohaterów za pomocą odczuwanych przez nich emocji. Twórcy zaczęli skupiać się na tematach wcześniej nieporuszanych i pisać o zjawiskach psychologicznych, mających pomóc w odkryciu prawdy o człowieku. Targani sprzecznymi uczuciami bohaterowie romantyczni funkcjo-

${ }^{7}$ Motyw kota pojawia się między innymi w twórczości E.T.A. Hoffmana, którym inspirował się Poe. W satyrycznej powieści Kota Mruczystawa poglądy na życie (obok fragmentów biografii kapelmistrza Jana Kreislera przypadkiem na strzepach makulatury zachowanych) (Lebens-Ansichten des Katers Murr nebst fragmentarischer Biographie des Kapellmeisters Johannes Kreisler in zufälligen Makulaturblättern, t. 1 - 1819, t. 2 - 1821; pol. 1958) zantropomorfizowany kot-narrator przedstawia historię swojego życia. Hoffmann miał kota Murra. O wyjątkowym przywiązaniu do zwierzęcia świadczy to, że po jego śmierci rozesłał do przyjaciół nekrolog.

${ }^{8}$ E.A. Poe, op. cit., s. 379; pisownia zgodna z oryginałem.

9 P. Kowalski, Kultura magiczna. Omen, przesad, znaczenie, Warszawa 2007, s. 241.

10 Zob. M. Swan, Historia kotów, przeł. M. Wojtyna, M. Aleksandrowicz-Wojtyna, Kraków 2015, s. 211.

11 E.A. Poe, op. cit., s. 388. 
nują na granicy obłędu. Twórcy zaczęli opisywać złożone i zmienne osobowości swoich bohaterów. Szaleństwo uznano za „chorobę wieku”. W pierwszej połowie XIX wieku odbyły się pierwsze procesy sądowe, w których niepoczytalność była okolicznością łagodzącą. Relacjami z takich procesów inspirował się Edgar Allan Poe. Ówcześnie zakładano, że mózg może przetwarzać informacje emocjonalnie i racjonalnie. Szaleństwo thumaczono uszkodzeniem ośrodka racjonalnego.

Jeśli przyjmiemy, że Poe podzielał ówczesne poglądy, to zadziwiający sposób prowadzenia narracji w jego opowiadaniach stanie się zrozumiały. Chodzi przede wszystkim o sposób zdystansowania bohaterów wobec ich własnych czynów. Narratorzy-bohaterowie u Poego zazwyczaj w przenikliwy, analityczny i pozbawiony emocji sposób referują najbardziej makabryczne szczegóły dokonanych przez siebie morderstw. Być może więc miały to być relacje przedstawione z perspektywy racjonalnej części umysłu, której istnienie zakładał pisarz. Przeświadczenie o istnieniu drugiej niezależnej struktury — emocjonalnej, która czasem całkowicie wymyka się spod świadomej kontroli [...] osadza abstrakcyjne rozważania Poego w kontekście ówczesnej nauki ${ }^{12}$.

W Czarnym kocie szaleństwo tłumaczone jest obsesją na punkcie tytułowego zwierzęcia. Bohater ma świadomość własnych zachowań, ale nie może uwolnić się od obłędu. Cierpi, krzywdząc kota, jednak nie potrafi powstrzymać się od okrucieństwa. Poe nawiązuje tu do wcześniej przeze mnie wspomnianej monomanii ${ }^{13}$ — kwestii chętnie podejmowanej przez pisarzy w pierwszej połowie XIX wieku, kiedy to wzrastało zainteresowanie ludzką psychiką. Częstym motywem twórczości Poego jest też perwersyjność, która pcha bohaterów do złego.

Indywidualizm bohatera romantycznego przejawiał się często $\mathrm{w}$ braku jakichkolwiek granic, także moralnych. Zbrodnia stała się popularnym motywem literackim. Antropologia romantyczna eksponowała temat dwoistości natury ludzkiej. Pogrążeni w obłędzie demoniczni bohaterowie nie wahali się przed popełnianiem okrutnych morderstw. W Czarnym kocie dokonana w paroksyzmie szaleństwa zbrodnia ma pomóc bohaterowi uwolnić się od własnej obsesji. Mimo że w wielu utworach Poego dochodzi do estetyzacji śmierci młodej kobiety, na przykład w Zagładzie domu Usherów (The Fall of the House of Usher, 1839; pol. 1897 jako Upadek domu Usherów, [w:] idem, Nowele) czy Annabel Lee (Annabel Lee, 1850; pol. 1910), tutaj sam narrator opisuje mord jako „ohydne zabójstwo"14. Gdy bohater próbuje zabić kota, żona powstrzymuje go ręką. „Rozgorzały iście demoniczną wściekłością" wbija siekierę w jej głowę.

12 E. Młożniak, Motyw perwersyjności w opowiadaniach „Bies przewrotności”, „Czarny kot" $i$,, Serce oskarżycielem" Poego, [w:] Edgar Allan Poe zwielokrotniony..., s. 52.

13 Twórcą terminu, powstałego około 1810 roku, jest francuski psychiatra, Jean-Étienne Dominique Esquirol, który wyróżnił trzy typy monomanii: emocjonalną, intelektualną oraz zdolności wolicjonalnych. Zob. https://en.wikipedia.org/wiki/Monomania (dostęp: 22.07.2018).

14 E.A. Poe, op. cit., s. 385. 


\section{Czarny kot $\mathrm{w}$ ujęciu modernistyczno-romantycznym - adaptacja Edgara G. Ulmera}

Sukces filmów Dracula (reż. T. Browning, USA 1931) i Frankenstein (reż. J. Whale, USA 1931) zapoczątkował nowy nurt w kinie amerykańskim. Zaczęło powstawać coraz więcej, klasycznych dziś, filmów o potworach. Gwiazdami ówczesnych monster movies stali się Bela Lugosi (znany z roli tytułowej w filmie Dracula, uważany za prawdziwego wampira, tajemniczy dżentelmen o staroświeckich manierach) i Boris Karloff, odtwórca głównych ról w filmach takich jak Frankenstein czy Mumia (The Mummy, reż. K. Freund, USA 1932). Twórcy filmowego horroru szybko sięgnęli także do dzieł Poego. Adaptacje jednak nie były wierne, zdarzało się nawet, że oprócz tytułu nic nie łączyło ich z oryginałem. Pierwszym ekranizowanym w latach trzydziestych dziełem Poego stało się Zabójstwo przy Rue Morgue (Murders in the Rue Morgue, USA 1932). Reżyserem filmu został Robert Florey, który pierwotnie miał realizować Frankensteina, zadanie oddano jednak Jamesowi Whale'owi, a Floreyowi wytwórnia Universal w ramach rekompensaty powierzyła zadanie reżyserowania Zabójstwa... Odtwórcą głównej roli został znany już Bela Lugosi. Nie zagrał on jednak, jak można by przypuszczać, Auguste'a Dupina, lecz wcielił się w niepojawiającego się w opowiadaniu Doktora Mirakle. Mimo wielkiej gwiazdy w obsadzie filmowi nie udało się przetrwać próby czasu.

Wkrótce władze wytwórni Universal postanowiły zdyskontować sukces filmów o potworach, tworząc serię horrorów, w których Lugosi i Karloff występowali razem. Pierwszy wspólny film czołowych gwiazd wytwórni to Czarny kot (The Black Cat, USA 1934) w reżyserii Edgara G. Ulmera. Również w tej ekranizacji trudno doszukać się powiązań z literackim pierwowzorem. Film ukazuje młode małżeństwo w podróży poślubnej, które w pociągu poznaje doktora Vitusa Werdegasta (Lugosi). Na skutek nieoczekiwanych zdarzeń para trafia wraz z Werdegastem do domostwa jego dawnego przyjaciela Hjalmara Poelziga (Karloff), który później okazuje się niebezpiecznym wyznawcą szatana. Werdegast w rzeczywistości przybywa do Poelziga, by zemścić się na nim, ten bowiem zrujnował mu życie i doprowadził do wielkiej osobistej tragedii. Nowela Poego została przełożona na realia współczesne. Bohaterowie wciąż pamiętają pierwszą wojnę światową, która wpłynęła na ich życie, a ukazane wydarzenia są następstwami wojennego dramatu Werdegasta i Poelziga. W filmie występuje tytułowy kot. Jako drugorzędny motyw ma jednak niewielkie znaczenie dla rozwoju fabuły, przyczynia się natomiast do wykreowania aury tajemniczości i niesamowitości. Pełni też praktyczną funkcję związaną z motywacją zachowań postaci: kot należy do Poelziga, zwierzęcia panicznie boi się Werdegast, cierpi bowiem na ailurofobię (lęk przed kotami). Czarnego kota uważa się za ostatni przykład niemieckiego ekspresjonizmu. Na pochwałę zasługują kreacje Lugosiego i Karloffa. Mimo bra- 
ku podobieństwa do oryginału film utrzymany jest w atmosferze grozy godnej opowiadań Poego.

Tajemnicza, pełna cierpienia przeszłość, tragizm losu, pragnienie zemsty, wrażliwość - te cechy czynią z granego przez Belę Lugosiego doktora Vitusa Werdegasta bohatera romantycznego. Tragiczna historia nie daje o sobie zapomnieć i skłania go do dokonania zemsty na swoim największym wrogu Hjalmarze Poelzigu. Węgier Werdegast w czasie pierwszej wojny światowej walczył za cesarza, Austriak Poelzig zostawił swojego towarzysza broni na pewną śmierć i zdradził go, po czym związał się z jego żoną, a po jej śmierci z córką przyjaciela. Węgierski psychiatra przeżył jednak i wyruszył w podróż, która miała dać mu odpowiedź na pytanie o losy jego żony i córki, a także przynieść sprawiedliwość. Mimo doznanych krzywd Werdegast nie jest bohaterem bez winy. W okrutny sposób bierze odwet na wrogu, próbując zadośćuczynić swoim krzywdom. Z kolei Poelziga z bohaterami romantycznymi łączy demoniczność. Ironiczny i nieprzewidywalny morderca i wyznawca szatana, a przy tym wybitny architekt, wzbudza grozę. Bohater nie jest szaleńcem. W swoim okrucieństwie jest racjonalny, a jego czyny są przemyślane. Jest też estetą, który trupy pięknych, zamordowanych przez siebie kobiet trzyma w formalinie. Okrucieństwo obydwu bohaterów, problemy emocjonalne Werdegasta i sytuacja graniczna, czyli ich ostateczne starcie, zakończone śmiercią każdego $\mathrm{z}$ nich, to cechy łączące film z napisanym przez Poego pierwowzorem.

W filmie wspomniano o starożytnych wierzeniach, zgodnie z którymi czarny kot to wcielenie zła. W momencie śmierci zwierzęcia zło przechodzi na najbliższą istotę. Widz otrzymuje pewne sygnały, że Werdegastowi i Poelzigowi właśnie dzięki temu udało się przeżyć wojnę, a sami bohaterowie są czymś na kształt żywych trupów. Wyznający kult szatana architekt interesuje się czarną magią i mógł posłużyć się nią, by przeżyć. Stąd prawdopodobnie wzięła się też fobia psychiatry. Hjalmar Poelzig i jego służący ucharakteryzowani zostali nawet w taki sposób, że nieco przypominają koty.

Ulmer szaleństwo thumaczy w sposób naukowy. Vitus Werdegast cierpi na ailurofobię - lęk przed kotami. Gdy tylko zauważa zwierzę w domu swojego wroga, rzuca w nie nożem i zabija. Sam bohater jest wybitnym psychiatrą. Postrzeganie szaleństwa staje się więc nowoczesne, powiązane z nauką medyczną (psychiatrią) i psychologiczną (elementy psychoanalizy). Możemy też przypuszczać, że bohater prowadzi autoanalizę, lecz nie jest w stanie uwolnić się od swej obsesji. Hjalmar Poelzig przypomina Werdegastowi o jego chorobie i próbuje wpędzić go w obłęd. Prawdziwe szaleństwo jednak opanowuje granego przez Belę Lugosiego bohatera w chwili zemsty, na którą czekał wiele lat. Możliwość dokonania mordu na człowieku, który zniszczył mu życie, wywołuje w bohaterze pełną perwersji radość. Okrutna zbrodnia jest zwieńczeniem całego filmu. Vitus Werdegast mści się na swoim dawnym oprawcy, odzierając go ze skóry.

Atmosfera śmierci towarzyszy bohaterom przez cały czas. Hjalmar Poelzig trzyma w piwnicy budynku własnego projektu, uznanego za arcydzieło nowo- 
czesnej architektury, trupy zamordowanych przez siebie kobiet, w tym żony Werdegasta. Zakonserwowane zwłoki zanurzone są w wielkich akwariach, a Poelzig napawa się nimi, niczym kolekcją dzieł sztuki. Mówi, że trzyma je tu, bo chciał zachować ich piękno na zawsze. Może to powodować skojarzenia z żoną głównego bohatera opowiadania Poego, zamurowaną we wnęce piwnicznej ściany.

Film Edgara G. Ulmera rozpoczyna się w nocy. Jest ogromna ulewa i rozpętuje się burza. Miejsce akcji nie daje zapomnieć o niedawnej pierwszej wojnie światowej. Dom architekta Poelziga nazwany jest „arcydziełem konstrukcji wzniesionym na miejscu arcydzieła destrukcji”. Budynek stoi bowiem w miejscu „największego cmentarza na świecie”, scenie masowej zbrodni, dokonanej podczas wojny. Dom położony jest na odludnym wzgórzu. Jego wnętrza mają charakter romantyczno-modernistyczny. Oprócz nowoczesnych udogodnień znajdują się tu rzucające długie cienie krzywizny i kręte klatki schodowe. Scenografia nawiązuje do estetyki niemieckiego ekspresjonizmu. Mamy tu do czynienia z gotycyzmem unowocześnionym. Zniekształconą rzeczywistość można interpretować także jako projekcję umysłu bohatera. Według Jerzego Płażewskiego ekspresjoniści, do których nawiązuje reżyser, ,kazali nam wierzyć, że stan ducha bohatera da się wyrazić przez wizję świata, który tamten ogląda" 15 . Taka interpretacja rodzi jednak pytanie - z czyją wizją mamy do czynienia? Żądnego zemsty Werdegasta? A może niepozornego Petera - pisarza w podróży poślubnej, przypadkowo zaplątanego w dramatyczną akcję, z którego punktu widzenia odbiorca poznaje przedstawioną rzeczywistość? Bohater i jego żona nieoczekiwanie stają się świadkami niezwykłych zdarzeń. Podobnie jak odbiorcy są obserwatorami przybyłymi z zewnątrz. Poczucie obcości i niepokoju związane z wypadkiem na drodze i znalezieniem się w nowych realiach może zniekształcać świat postrzegany przez Petera. Nie należy też zapominać o jego wybujałej wyobraźni — atrybucie literata.

\section{Makabra, groteska i surrealizm - zabawa Rogera Cormana z literackim pierwowzorem}

Kino lat sześćdziesiątych wraca do gotyckich inspiracji. Powstaje wtedy seria adaptacji romantycznych opowiadań Poego w reżyserii Rogera Cormana. Były to filmy komercyjne, kręcone w ramach niewielkiego budżetu, a jednak dobrze odwzorowywały niesamowitą atmosferę wykreowaną przez pisarza. Główną rolę odgrywa w nich tajemniczy Vincent Price ${ }^{16}$ — aktorska ikona horroru. „Dekadencja i poczucie ironicznego humoru to dwie cechy w sposób niezrównany sugero-

15 J. Płażewski, Język filmu, Warszawa 1961, s. 404.

16 Z wyjątkiem filmu Przedwczesny pogrzeb (Premature Burial, reż. R. Corman, USA 1962), w którym Price nie mógł zagrać ze względu na kontrakt podpisany z wytwórnią AIP. Zob. M. Whitehead, Roger Corman, Harpenden 2003, s. 58. 
wane przez Vincenta Price’a. Uznać je trzeba za klucz do interpretacji Poego"17 — pisze Andrzej Kołodyński. Cyk1 jest jednolity dzięki warstwie wizualnej. Filmy realizowane były w technice Pathé-color, w której przeważały wyraziste barwy czerwone i zielone. Efekt jest nieco sztuczny, ale dzięki niemu rzeczywistość nabiera cech onirycznych. Jako że Poe wiele pozostawia w sferze niedomówien, ekranizacje jego dzieł są często bardzo swobodne. Cyklowi Cormana zarzucano niewierność w stosunku do oryginału.

Reżysera interesuje obraz rozkładu pewnego świata, jego dekadencji. Odnalazł atmosferę i szczegóły potrzebne do wyrazistego przedstawienia tej wizji nie w poszczególnych utworach Poego, ale w całej jego twórczości i uczynił z tego własny, obsesyjny temat ${ }^{18}$.

Adaptacja Czarnego kota współtworzy cykl Opowieści niesamowite (Tales of Terror, USA 1962), złożony z trzech filmowych nowel. Reżyser łączy tu elementy Czarnego kota i Beczki Amontillado (The Cask of Amontillado, 1846; pol. 1813 jako Beczka Amontillada). Corman zdecydował się na konwencję humorystyczną, co zostało dobrze odebrane przez publiczność ${ }^{19}$. Montresor Herringbone (Peter Lore) pogrąża się w nałogu alkoholowym, zaniedbując swoją młodą żonę, która całe dnie spędza w domu wraz z czarnym kotem. Pewnego dnia w miasteczku pojawia się wybitny znawca trunków Fortunato Luchresi (Vincent Price), którego główny bohater wyzywa na pojedynek. Panowie upijają się, po czym udają się do domu Montresora. Tam Fortunato, zauroczony urodą żony Montresora, nawiązuje z nią bliską relację, a ich przyjaźń wkrótce przeradza się w romans. Gdy główny bohater dowiaduje się o tym, zabija ich, podobnie jak w literackim pierwowzorze, a zwłoki zamurowuje w piwnicy. Nie zauważa jednak, że zamurowany został też czarny kot. Reżyser porzuca rozważania autora na temat natury ludzkiej, perwersji i skłonności do czynienia zła. Skupia się na duchu parodystycznym, odzierając horror z grozy. Odtwórcy głównych ról, znani głównie z mrocznych filmowych horrorów, doskonale sprawdzają się, grając bohaterów będących komediowym przekształceniem ich wcześniejszych ról.

Główny bohater to niezdarny pijaczek nieprzepadający za kotem swojej żony, która większą czułością obdarza zwierzę niż swojego męża. Podobnie jak bohater opowiadania Montresor nie jest osobą wiarygodną. O wszystkie niepowodzenia oskarża czarnego kota i w przypływach szału rzuca w niego różnymi przedmiotami. Z kolei jego adwersarz, Fortunato, podziwia zwierzę, co denerwuje Montresora. Gdy zasypia, kot siada na nim niczym zmora w dawnych wierzeniach ludowych. Występuje też w jego koszmarze sennym.

Alkohol wywołuje u bohatera prowadzące do szaleństwa halucynacje. W wizjach tych wszystko jest nienaturalnie porozciągane i rozmyte, ludzkie twarze stają

17 A. Kołodyński, Seans z wampirem, Warszawa 1986, s. 151.

18 Ibidem.

19 T. Rutkowski, Pogrzebani żywcem. Filmowe adaptacje utworów Poego w reżyserii Cormana, [w:] Edgar Allan Poe zwielokrotniony..., s. 239. 
się wykrzywione, a Montresora zaczynają otaczać węże i jaszczurki ${ }^{20}$. W nocy śni mu się, że jego ofiary odrywają mu głowę i podrzucają ją jak piłkę. Jego ciało bezskutecznie próbuje im ją odebrać. Motyw ciała pozbawionego głowy pojawia się też w nowelach Poego, między innymi w Nigdy nie zakladaj się z diablem o swa glowę (Never Bet Your Head, 1841; pol. 1956) i Przykra historia (A Predicament, 1838; pol. 1956). Reżyser inspiruje się nie tylko poetyką romantyzmu, lecz także surrealizmem. Ukazanie koszmarów sennych, a więc sfery nieświadomości, wpisuje się w założenia wypracowane przez zwolenników dwudziestowiecznego nurtu ${ }^{21}$. Połączenie marzenia sennego i niepowagi obecne jest w filmie Cormana. Absurdalność wydarzeń sekwencji onirycznych odzwierciedlają stan psychiki bohatera. W filmie Cormana większość scen rozgrywa się w nocy. To właśnie o tej porze Montresor ma zwyczaj się upijać. Doznaje wtedy przerażających wizji i lawiruje na granicy obłędu. Przestrzeń jest jednak labiryntowa tylko w umyśle bohatera. Inne postacie nie czują się w miejscu zdarzeń obco ani nieswojo.

Gdy po adresem bohatera padają słowa: „Jest Pan szalony!”, ten odpowiada „Może, ale bardzo sprytny”. Tak samo jak w literackim pierwowzorze jasność myślenia łączy się tu z okrutnymi czynami. Gdy dowiaduje się o romansie żony z Fortunatem, postanawia się na nich zemścić. Podaje kochankowi żony „wino z piwnicy na specjalną okazję”, a gdy ten wypija je ze smakiem, bohater woła „Za pańskie życie!”. Wino usypia Fortunata na jakiś czas, co pozwala Montresorowi przykuć go do ściany obok uwięzionej wcześniej w ten sam sposób żony i zamurować ich razem w akcie zemsty. Pisk zwierzęcia doprowadza do zdemaskowania morderstwa. Adaptację utrzymano w pastiszowym tonie, którego celem jest zdystansowanie się od reguł gatunku. Choć horror miesza się z komedią także u Poego, Corman intensyfikuje i rozszerza aspekty humorystyczne, co dowodzi nie tylko doskonałej znajomości literackiego pierwowzoru, lecz także samoświadomości twórczej. Montresor to wywołująca śmiech wersja bohatera-narratora wykreowanego przez Poego. Cechy nadane mu przez pisarza są tu wyolbrzymione i ośmieszające.

Corman, który obawiał się, że filmy będą zbyt jednolite wizualnie, a przez to nużące dla widza, postanowił zdynamizować je odpowiednimi ujęciami kamery

20 Rozpoznawalnym wyznacznikiem stylu adaptacji twórczości Poego zrealizowanych przez Cormana są oderwane kompozycyjnie od fabuły sekwencje oniryczne. W przejaskrawiony sposób ukazują one największe lęki bohaterów. Sekwencje charakteryzują się zniekształconą perspektywą, rozmytym obrazem, a także przechyleniem i rozciągnięciem prezentowanej rzeczywistości. Taki sposób kreowania obrazu pozwala widzowi utożsamić się ze sposobem postrzegania świata przez pogrążonego w alkoholizmie bohatera. Jak pisze Jerzy Płażewski: „Zdjęcia zdeformowane nie odbijają, nie chcą odbijać rzeczywistości. Zamiast odbijać - interpretują one rzeczywistość [...] reprezentując psychikę określonej postaci dramatu" (J. Płażewski, op. cit., s. 126.).

${ }^{21}$ Centralne znaczenie snu w programie surrealistów zostało sformułowane już w pierwszym Manifeście surrealizmu André Bretona z 1924 roku. Autor wiele miejsca poświęcił rozważaniom na temat marzenia sennego. Nie brakuje w nim jednak — jak zauważył Adam Ważyk — atmosfery zabawy. Zob. Surrealizm. Teoria i praktyka literacka. Antologia, przedm. A. Ważyk, Warszawa 1976, s. 10. 
i szybkim montażem. Pozbawiające obraz statyczności ruchy kamery stały się jednym z wyznaczników stylu gotyckiego cyklu. Jak pisze Kołodyński:

Corman odnalazł własny klucz wizualny, komponując obrazy w poziomym układzie ekranu CinemaScope. Ciasnotę przestrzeni niwelują proste sposoby: dekoracje toną w sztucznej mgle i nigdy nie zostaną ukazane w planie ogólnym, ponieważ kamera znajduje się w ciągłym ruchu. Szerokie panoramy i travellingi zmieniają stale perspektywę i narzucają obrazowi wyraźny rytm. Pod tym względem jest nie lada rzemieślnikiem: lubuje się zwłaszcza w zestawieniach przeciwstawnego ruchu (kamera przesuwa się w kierunku przeciwnym do poruszających się osób), ma instynktowne wyczucie proporcji, długości poszczególnych sekwencji. Jest to sprawność nieco akademicka, ale dzięki temu każdy z jego kostiumowych obrazów pulsuje prawdziwie filmowym życiem, hipnotycznie przyciąga uwagę widza ${ }^{22}$.

Dzięki takim zabiegom poddaną teatralizacji rzeczywistość pozbawiano statyczności. Reżyser, który lubił stosować eksperymentalne rozwiązania operatorskie, tworzył atrakcyjne sceny, angażujące uwagę i emocje odbiorcy. Według Dudzińskiego zabiegi te ,są niezwykle trafione i w połączeniu z niezwykłą kolorystyką i mise-en-scène, stają się ekwiwalentem stylu narracji Poego"23. Nietypowe rozwiązania wizualne zwróciły też uwagę krytyków - najpierw europejskich, a później amerykańskich. Corman uważał, że zawdzięczał ją między innymi sposobowi prowadzenia kamery wzmagającego u widza napięcie i strach.

\section{Poe jako twórca i bohater - postmodernistyczna wariacja Stuarta Gordona}

Charakterystyczną cechą ekranizacji opowiadań Poego jest niewierność oryginałowi. Pisarz pozostawia wiele niedopowiedzeń, dając pretekst dla własnych interpretacji adaptatorów bądź odbiorców. Jednak Czarny kot doczekał się wiernej adaptacji, która w zaskakujący sposób miesza fikcję literacką z autentycznymi wydarzeniami. Film Stuarta Gordona Czarny kot (The Black Cat, USA 2005) jest częścią serii Mistrzowie horroru (Masters of horror, USA 2007). Jej głównym założeniem było tworzenie niepowiązanych z sobą fabularnie odcinków, wyreżyserowanych przez uznanych twórców kina grozy. Film jest o tyle interesujący, że jego głównym bohaterem uczyniono samego Poego. Fabułę Czarnego kota przekonująco połączono z biografią pisarza. Tak jak główny bohater opowiadania ojciec fantastyki grozy cierpiał na alkoholizm. Poe przeżywa kryzys twórczy, a gruźlica żony Virginii wpędza go w depresję. W dodatku bohater negatywnie reaguje na ulubieńca ukochanej, tytułowego czarnego kota. Doskonale odwzorowana fabuła przesycona jest atmosferą grozy, większą nawet niż w literackim pierwowzorze.

22 A. Kołodyński, op. cit., s. 149.

23 P. Dudziński, ,Poe jest całkiem pop”. Uwarunkowania kulturowe twórczości filmowej na przyktadzie Rogera Cormana, [w:] Ogrody nauki i sztuk. Debiuty 2010, red. A. Kobylark, Wrocław 2010, s. 260. 
Zamierzona dwuznaczność sprawia, że widz ma trudność z rozpoznaniem tego, co w filmowej rzeczywistości dzieje się naprawdę, a co jest wytworem alkoholowych wizji bohatera, widocznych tylko dla niego. Rzeczywistość i fikcja nie różnią się od siebie wizualnie, a pozornie linearny montaż celowo wprowadza widza w błąd. Pojawia się tu tak typowa dla gatunku krew, nadająca plastyczności niesamowitym scenom. Chora na gruźlicę Virginia wypluwa ją, zanosząc się kaszlem. Edgara nie stać nawet na leki dla żony, jednak nie jest w stanie zmobilizować się do pracy twórczej. Alkoholizm pogłębia tylko jego nieszczęście.

W przeciwieństwie do poprzednich opisywanych przeze mnie ekranizacji tej noweli dobrze zobrazowano tutaj monomanię, do której nawiązywał Poe. Osoby na nią cierpiące zatracały zmysł moralny, nie tracąc trzeźwości umysłu, co pozwalało im popełniać okrutne zbrodnie. U Poego owładnięci monomanią bohaterowie sami ujawniają swe zbrodnie. W opisywanej ekranizacji psychika bohatera każe mu przyznać się do nieumyślnie popełnionego morderstwa. Kiedy widz orientuje się, co zamierza zrobić bohater, sam ma ochotę go powstrzymać przed zdemaskowaniem się i utrzymywać jego zbrodnię w tajemnicy. Dochodzi tu do mechanizmu identyfikacji, dzięki któremu odbiorca odkrywa własną mroczną stronę. W adaptacji pojawia się też nawiązanie do opowiadania Serce oskarżycielem (The Tell-Tale Heart, 1843; pol. 1913), które również porusza temat monomanii. Kiedy Poe udaje się do wydawcy, ten chwali jego wcześniejsze opowiadanie - Serce oskarżycielem, o starcu, który miał dziwaczne, niezwykle jasne oko. Sam wydawca także ma takie oko, a Poe, niczym bohater własnego opowiadania, patrzy na nie z niesmakiem. W ekranizacji pojawia się więcej specyficznego poczucia humoru, które nieco rozluźnia atmosferę. Występują tu postacie, z którymi Poe miał do czynienia w rzeczywistości, na przykład Rufus Griswold, literacki adwersarz pisarza ${ }^{24}$. Ekranizacja Gordona to przede wszystkim opowieść o żmudnym procesie twórczym i jego inspiracjach. Jest to najwierniejsza jak do tej pory adaptacja filmowa noweli Poego, której twórca zaprasza odbiorcę do postmodernistycznej gry polegającej na odnajdowaniu nawiązań intertekstualnych.

${ }^{24}$ Literacki spór Poego i Griswolda, amerykańskiego poety, krytyka i wydawcy, rozpoczął się po opublikowaniu antologii poezji amerykańskiej The Poets and Poetry of America (Poeci i poezja Ameryki, 1842). Griswold dokonał wyboru zamieszczonych utworów z myślą o zrealizowaniu postulatu Poego o reformowaniu rodzimej sceny literackiej. Ten uznał jednak, że zbyt wiele miejsca poświęcono poezji niegodnej uwagi, pomijając przy tym tę najbardziej wartościową. Jego nieprzychylna recenzja wpłynęła na wzajemne relacje literatów, których spór toczył się nie tylko w prywatnej korespondencji, lecz także na łamach prasy. Po śmierci Poego, której przyczyn nigdy nie udało się ustalić, w „New York Tribune” ukazał się, mający na celu zniesławienie zmarłego, nekrolog, zaczynający się od słów: „Edgar Allan Poe nie żyje. Zmarł przedwczoraj w Baltimore. Ta wiadomość zaskoczy wielu, ale niewielu zasmuci” („Edgar Allan Poe is dead. He died in Baltimore the day before yesterday. This announcement will startle many, but few will be grieved by it”). Był on podpisany pseudonimem „Ludwig”. Jak się później okazało, jego autorem był Griswold. Zob. S.P. Moss, Poe’s Literary Battles: The Critic in the Context of His Milieu, New York 1969. Spór wpłynął także na legendę biograficzną Poego i pobudził masową wyobraźnię. Skomplikowanej relacji poetów N. Frobenius poświęcił powieść Pokażę wam strach (Jeg skal vise dere frykten, 2008; pol. 2009). 
Postać Poego jest tu typem bohatera romantycznego, który cierpi, ale mimo starań nie potrafi zmienić swojej sytuacji. Alkohol popycha go do szaleństwa i wpędza w biedę. O swoje czyny, dokonane podczas napadów szału, oskarża kota i nie przyznaje się do winy. „Coś pcha mnie do złego. Do krzywdzenia bliskich i samego siebie" — mówi bohater. Cierpienia przysparza mu także blokada twórcza i niemożność napisania czegokolwiek. Jest to tym bardziej bolesne, że tylko dzięki tworzeniu swoich dzieł jest w stanie zarobić pieniądze i pomóc ukochanej Virginii. Warto zwrócić uwagę na scenę, w której bohater spotyka się z wydawcą, by zaproponować mu swoją poezję. Ten jednak odrzuca ofertę, szydząc, że poezja dobra jest dla kobiet, on natomiast oczekuje krwawej opowieści fantastycznej. Poe upija się i wraca do żony, u której następuje atak spowodowany chorobą. Relacja poezja-kobiety-choroba odgrywa tu znaczącą rolę. Wydaje się, że są to czynniki bliskie sobie i współwystępujące. Choroba, kojarzona z kobiecością, to oznaka słabości, wymowne jest dodanie przez twórców filmu do tego ciągu pojęć poezji. Całą historię można interpretować jako metaforę procesu twórczego, który wymaga wysiłku, oddania emocjonalnego, wewnętrznej walki, a ostatecznie zwycięstwa i doprowadzenia pracy do końca. Filmowcy odnaleźli wspólne cechy autora i postaci, które opisywał, po czym połączyli je w sugestywną całość. Tym samym Poe został włączony w szereg swoich bohaterów.

Film Gordona rozpoczyna się od ujęcia z czarnym kotem. Od samego początku zwierzę zachowuje się tak, jakby chciało zabronić bohaterowi kontaktu z żoną. Gdy Edgar próbuje dotknąć Virginii, jej pupil o imieniu Pluton rzuca się na niego z pazurami. Kiedy żona bohatera śpi, kot siada na niej i nie chce zejść, dlatego Edgar boi się, że Virginia udusi się podczas snu. Zwierzę przeszkadza mu nawet podczas próby samobójczej. W rezultacie na przygotowanej dla siebie pętli bohater wiesza kota. Wkrótce w mieszkaniu pisarza pojawia się sobowtór Plutona. Kiedy Edgar, po popełnieniu zbrodni, prowadzi zdezorientowanych policjantów do piwnicy, rozlega się dźwięk przypominający krzyk kobiety. Okazuje się jednak, że to nieopatrznie zamurowany kot.

W porównaniu z omawianymi wcześniej ekranizacjami zbrodnia w ujęciu Gordona wydaje się najbardziej okrutna. Gdy Edgar wbija siekierę w głowę Virginii, leją się strumienie krwi. Kobieta z przepołowioną głową stoi przez chwilę na schodach, a potem się przewraca. Przeniesienie i zamurowanie ciała sprawia bohaterowi wiele trudu. Gordon nawiązuje do krwawej estetyki filmów gore, przepełnionych brutalnością. Podobny styl reprezentują też inne filmy z cyklu Mistrzowie horroru.

Film Gordona utrzymany jest w ciemnych barwach. Kontrastuje z nimi często pojawiająca się na ekranie krew, która zdaje się zalewać całą ukazaną przestrzeń. Szaleństwo dotyka bohatera w nocy, choć tutaj nawet dzień jest ciemny i przypomina noc. Kolory stają się jaśniejsze w ostatniej scenie, w której Edgarowi udaje się przezwyciężyć kryzys twórczy i zaczyna pisać. Można więc wnioskować, że świat jest mroczny jedynie w wyobraźni bohatera, a barwa na ekranie staje się 
korelatem stanów psychicznych postaci. Taki sposób operowania środkami filmowego wyrazu wpłynął na atrakcyjność filmu w oczach odbiorców.

\section{Zakończenie}

Sygnowanie filmów nazwiskiem pisarza sprowadzało publiczność do kin. Mimo iż horrory okazywały się swobodnymi interpretacjami jego dzieł, budziły podobną do wykreowanej przez Poego atmosferę grozy. Tu zapewne należy widzieć źródło sukcesu owych adaptacji, będących nie tyle wiernym przeniesieniem na ekran opowiadań amerykańskiego twórcy, ile próbą odnalezienia ich ekwiwalentu i oddziaływania na odbiorcę za pomocą środków właściwych sztuce filmowej.

Założenia estetyczne Poego mają charakter uniwersalny. Wypracowane przez niego koncepcje powracają w późniejszych epokach, a także innych, nowych dziedzinach sztuki, na przykład filmie. Historia, przepełniona typową dla gotycyzmu atmosferą niepokoju, zdaje się aktualna także w XX i XXI wieku. Niektóre jej elementy zostają przeobrażone i dostosowane do czasów, w których dokonuje się reinterpretacji romantycznych dzieł (na przyklad w biografii Vitusa Werdegasta pojawiają się niedawne wydarzenia związane z pierwszą wojną). Wielu twórców podobnie jak E.G. Ulmer traktuje pierwotny tekst jako punkt wyjścia do własnych modyfikacji i reinterpretacji w duchu współczesnych im czasów. Inni natomiast starają się zachować wierność fabularną w stosunku do pierwowzoru (S. Gordon), zadowalając się rewokacją literackiego wzorca i przekładem intersemiotycznym. Nietrudno zauważyć właściwość, która łączy obydwa typy nawiązań — opowieści grozy w każdej kolejnej dekadzie są zdolne wyrazić aktualne lęki społeczne i niepokoje jednostek.

W omawianych adaptacjach można odnaleźć ponadto elementy romantycznej antropologii bohaterów, charakterystycznej dla twórczości Poego. Przejawiają się one w specyficznej konstrukcji postaci, które cechowało między innymi rozdwojenie jaźni. Jak pisze Sławomir Studniarz,

fundamentalny dualizm rzeczy, różnorakie przejawy opozycji właściwe rzeczywistości przedstawionej obejmują również naturę ludzką. Człowiek jest ambiwalentny, obciążony podstawową antynomią bytu, którą w sobie odzwierciedla, co w nowelach Poego znajduje wyraz w rozmaitych motywach podwojonego istnienia ${ }^{25}$.

Wewnętrzne rozdarcie ujawnia się niekiedy w postaci przekory cechującej niektórych bohaterów Poego, fatalnej siły, której ulegają, choć wiedzą, że doprowadzi ich do upadku. Ów przemożny impuls dotyka także protagonisty opowiadania Czarny kot, które poświęcone zostało analizie przejawów tego „pierwotnego, irracjonalnego impulsu duszy ludzkiej" ${ }^{26}$. Ciąg tragicznych zdarzeń uruchamia

25 S. Studniarz, Tragiczna wizja. Rzecz o nowelistyce Poego, Szczecinek 2018, s. 146.

26 Ibidem, s. 153. Drugim opowiadaniem dotyczącym tego zagadnienia jest Duch przekory. 
skłonność bohatera do nadużywania alkoholu. „Działając pod wpływem przekory, postaci przestają jak gdyby być sobą, stają się narzędziem jakiejś innej, nieodpartej siły"27. Bohater ulega fatalizmowi, choć wie, że doprowadzi go to do zguby. Wydaje się uwięziony we własnej wewnętrznej rzeczywistości psychicznejej ${ }^{28}$. W filmie Ulmera Werdegast ujawnia oblicze szaleńca pod wpływem narastającego pragnienia zemsty, przebytych traum i dręczącej go fobii. Przeżycia psychiczne stają się bodźcem porównywalnym do alkoholu z pierwowzoru literackiego - czynnika, który sprawia, że bohater ujawnia skrywaną dotąd przed światem stronę własnej natury. Montresor z adaptacji Cormana właśnie pod wpływem alkoholowych wizji wyznaje winę, co doprowadza go do upadku. Jednak jego porażka wywołuje uśmiech politowania, w przeciwieństwie do klęski Poego, bohatera filmu Gordona.

Dokonywane w kolejnych epokach adaptacje umieszczały opowieść Poego w nowych kontekstach kulturowych i zmieniały jej wydźwięk. Wpływ na kształt ekranizacji miały między innymi warunki społeczne i historyczne, dominujące prądy estetyczne, wyobraźnia adaptatora oraz zapotrzebowania odbiorców. Na przykładzie Czarnego kota można dostrzec, że romantyczna literatura grozy wywarła znaczący wpływ na filmowy horror. Choć w kolejnych odczytaniach noweli zmieniała się przestrzeń i sceneria wydarzeń, towarzyszyła im specyficzna, rozpoznawalna aura niedopowiedzenia i tajemniczości. Analogię można dostrzec także w sposobie oddziaływania na odbiorcę: filmowy horror, podobnie jak gotycka nowela grozy, pozbawia go poczucia pewności i bezpieczeństwa, wprawiając w „bojaźń i drżenie”. Podsumowując, można przywołać słowa Noela Carrolla o tym, że horror staje się szczególnie popularny w czasach społecznych napięć ${ }^{29}$. A te, zarówno dawniej, jak i dziś, wymagają psychologicznej i artystycznej odpowiedzi. Dlatego też horror pozostaje bliski tak wielu twórcom i odbiorcom.

\section{Bibliografia}

\section{Teksty}

Poe E.A., Opowiadania, przeł. S. Wyrzykowski, t. 1, Czytelnik, Warszawa 1989.

\section{Opracowania}

Brzostek D., Literatura i nierozum. Antropologia fantastyki grozy, Wydawnictwo UMK, Toruń 2009.

Carroll N., Filozofia horroru, albo paradoksy uczuć, przeł. M. Przylipiak, słowo/obraz terytoria, Gdańsk 2004.

27 Ibidem.

28 Ibidem, s. 134.

29 N. Carroll, Filozofia horroru, albo paradoksy uczuć, Gdańsk 2004, s. 348. 
Dudziński P., „Poe jest całkiem pop”. Uwarunkowania kulturowe twórczości filmowej na przykładzie Rogera Cormana, [w:] Ogrody nauki i sztuk. Debiuty 2010, red. A. Kobylarek, A. Gil, A. Kozak, PSP, Wrocław 2010.

Has-Tokarz A., Horror w literaturze wspótczesnej i filmie, Wydawnictwo UMCS, Lublin 2010.

Kołodyński A., Seans z wampirem, Wydawnictwa Artystyczne i Filmowe, Warszawa 1986.

Kopaliński W., Przedmowa, [w:] E.A. Poe, Opowiadania, przeł. S. Wyrzykowski, Czytelnik, Warszawa 1989, s. 5-21.

Kowalski P., Kultura magiczna. Omen, przesą, znaczenie, Wydawnictwo Naukowe PWN, Warszawa 2007.

Młożniak E., Motyw perwersyjności w opowiadaniach „Bies przewrotności”, „, Czarny kot” i „Serce oskarżycielem" Poego, [w:] Edgar Allan Poe zwielokrotniony. W kręgu literatury, malarstwa i filmu, red. E. Szczęsna, P. Kubiński, Dom Wydawniczy Elipsa, Warszawa 2010.

Nalewajk Ż., Postać literacka w nowelistyce Poego. Zasady konstrukcji, [w:] Edgar Allan Poe zwielokrotniony. W kręu literatury, malarstwa i filmu, red. E. Szczęsna, P. Kubiński, Dom Wydawniczy Elipsa, Warszawa 2010.

Płażewski J., Język filmu, Książka i Wiedza, Warszawa 1961.

Rutkowski T., Pogrzebani żywcem. Filmowe adaptacje utworów Poego w reżyserii Cormana, [w:] Edgar Allan Poe zwielokrotniony. W kręgu literatury, malarstwa i filmu, red. E. Szczęsna, P. Kubiński, Dom Wydawniczy Elipsa, Warszawa 2010.

Studniarz S., Tragiczna wizja. Rzecz o nowelistyce Poego, Dom Horroru, Szczecinek 2018.

Swan M., Historia kotów, przeł. M. Wojtyna, M. Aleksandrowicz-Wojtyna, Znak, Kraków 2015.

Whitehead M., Roger Corman, Harpenden 2003.

\title{
Filmografia
}

Czarny kot, [w:] Mistrzowie horroru, reż. S. Gordon, USA 2005.

Czarny kot, [w:] Opowieści niesamowite, reż. R. Corman, USA 1962.

Czarny kot, reż. E.G. Ulmer, USA 1934.

\section{Edgar G. Ulmer - Roger Corman - Stuart Gordon. Movie adaptations of Edgar Allan Poe's short story The Black Cat}

\author{
Summary
}

The article entitled Edgar G. Ulmer - Roger Corman - Stuart Gordon. Movie adaptations of Edgar Allan Poe's short story "The Black Cat" is a comparative analysis of three adaptations of a gothic short story. The attempt at finding inspirations from romantic poetics in the works of film directors, created in different decades and answering the question of how is it possible to transfer assumptions of romantic literature into movie language, was made in this text. In the movie from 1934, Edgar G. Ulmer connects gothic poetics with modernism aesthetics. He also adds historical context, referring to events in the First World War. On the other hand, taking classic literature became an opportunity for Roger Corman to play with convention. He expresses it in the adaption from 1962, in which terror gives space to humour. Stuart Gordon in turn, creates a post-modern variation based on a theme of The Black Cat, making Poe himself the main character of the movie from 2005. The important criterion of interpretation includes the motives of the Byronic hero, cat, madness and crime. Analysis of different ways to re-interpret the gothic short story leads to conclusions about filmmakers' attitude to literary prototype. Also, the cultural context of individual adaptations was pointed out. 